\title{
KEMANDIRIAN ANAK ASUH DI PANTI ASUHAN YATIM ISLAM DITINJAU DARI KONSEP DIRI DAN KOMPETENSI INTERPERSONAL
}

\author{
Muhammad Lukman \\ Pusat Studi Agama dan Pengembangan Potensi Umat AAMAOANIA Yogya \\ INTISARI
}

Penelitian ini bertujuan untuk mengetahui hubungan antara kompelensi interpersonal dan konsep diri dengan $k$ emandirian, baik secara bersamasama maupun sendiri-sendiri. Hipotesis penelitian in adalah terdapat hubungan antara kompetensi interpersonal dengan kemandirian, terdapat: hubungan antara konsep diri dengan Kemandirian can terdapat hubungan ganda antara kompetensi interpersonal dan konsep diri dengan kemandirian anak asuh di panti asuhan yatim islam of Kota Yogyakarta.

Subjek penelitian ini adalah anak asuh di panti asuhan yatim islam Kota Yogyakarta yang berusia remaja (13-21 lahun). Panti asuhan yatim Islam of Kota Yogyakarta terdapat tiga panti asuhan, yaitu Panti Asuhan Yatim Putra Muhammadiyah, PantiAsuhan Yalim Putri isiam dan Panti Asuhan Yatim Putrl 'Alsyiyah. Subjek diambil secara iandom dengan berpedoman pada Tabel Kecjle, yaitu 85 subjek.

Alat ukur yang digunakan adalah angket kemandirian, angket kompetensi interpersonal dan angk konsep diri yang disusun oleh peneliti. Hasil penelitian menunjukkan; terdapat hubungan yang signifikan antara kompetensl intepersonal dengan kemandirian $(r=0,600)$, terdapat hubungan yang signifikan antara konsep ofli dengan kemandirian ( $r=$ 0,592). Hubungan ganda antara kompetensl interpersonal dan konsep diri dengan kemandirian tidak dapat dianalisis karena ierjadi kolinearitas antara oua varlabel bebas.

Kata Kunci: Kemandirian, Kompetensi Interpersonal, Konsep Diri.

Muhammad Lukman, Lahir O4 Oktober 1975, adalah alumnus Fakultas IImu Agama Islam UII Yogyakarta, Koordinator Divisl Penellian Yayasan insan Kamil tahun 1999. 2000 dan Staf Pusat Studi Agama dan Pengembangan Potensi Umat (PSAPPU) Ramadania Yogyakarta.

\section{PENDAHULUAN}

Q ikap kemandirian adalah satu sikap D yang harus ada pada diri setiap individu yang dewasa. Hal ini terkait erat dengan kepentingan setiap individu dalam mengarungi kehidupannya. Tanpa bekal sikap kemandirian, setiap individu akan mengarungi kehldupannya dengan ketidakpastian. Setiap ketidakpastian merupakan sebuah celah yang berpotensi menjadi jurang yang akan menelan mereka sendiri. 
Sikap mandiri berkembang dalam diri setiap orang dimulai dari ketergantungan yang semakin tipis dalam setiap diri individu terhadap orang lain. $\mathrm{Hal}$ ini ditandai dengan menipisnya pengarahan dari |uar, dan dikuti dengan semakin besamya ketergartungan terhadap diri sendini, sehingga pada gilirannya individu 'terbebas' dari pengaruh orang lain.

Upaya membina dan mengembangkan kemandirian bukanlah satu tugas yang mudah dapat dilakukan. Kemandirian tidak dapat terbentuk begitu saja, tetapi harus melalui proses yang panjang, yaitu proses yang membentuk pengalaman-pengalaman yang mengkristal menjadi sikap kemandirian. Secara individual, proses pembentukan dan pengembangan kemandirian dimulai ketika individu (anak) balita dan sudah matang ketika mampu berpikir rasional. Namun secara umum, proses pembentukan dan pengembangan pribadi mandiri sangat dipengaruhi oleh lingkungan individu bersangkutan, baik lingkungan tersebut adalan keluarga, sekolah, agama, budaya, maupun media iniormasi.

Tugas pembentukan dar pengembangan sikap mandiri memang merupakan tugas setiap individu, namun tugas tersebut menjadi semakin penting bila mengingat individu-individu tersebut adalah anak yatim dan atau piatu. Hal ini mengingat 'kesendirian' mereka dalam mengarungi kehidupan ini. Apabila mereka telah menjadi dewasa tanpa membawa bekal sikap pribadi mandiri, maka dikuatirkan mereka menjadi pribadi yang terlantar.

Keterlantaran mereka adalan sebuah tanggungjawab masyarakat yapgkadang terabaikan, baik secara moral agama maupun sosial. Mengabaikar tanggung jawab tersebut merupakan kelalaian yang dikutuk oleh agama. Al Qur'an secara tegas mengungkap bahwa mereka yang mengabaikan tanggungjawab terhadap anak yatim dan ataus piatu disebut dengan orang-orang yang mendustakan agama (Al-Qur'an Surat Ma'un, 107:1-2).

Membentuk dan mengembargkan pribadi atau individu yang berkepribadian mandir: bagi anak yatim dan atau piatu selama ini secara institusional sudah ditangani oleh lembaga penyantun anak yatim dan atau piatu. Lebih dari itu demi kepentingan menyantuni anak yatim dan atau piatu ini, Undang-Undang Dasar Negara ini telah menulisnya dengan jelas.

Walaupun sudah ada lembaga yang menangani anak yatim dan atau piatu ini, bukan berarti masyarakat luas dapat berpangku tangan. Mereka semestinya ikut andil dan berpartisipasi dalam menyiapkan anak-anak yatim dan atau piatu tersebut untuk lebih dapat 'bersaing' dalarn kehidupan ini, terutama setelah mereka keluar dari panti astuhan (lembaga penyantun), baik dengan partisipasi dalam bentuk dana, jabatan, tenaga, maupun pikiran.

Walaupun keharusan (yang bersifat kifayah) dalam partisipasi membentuk dan mengembangkan anak-anak yatim dan atau piatu ini sangat penting, namun peneliti melihat (sejaun pengamatan peneliti) masih minimnya perhatian para akademisi atau para ilmusar tethadap perkembangan kemandirian anak asuh panti asuhan yatim. Hal ini dapat dilihat dari minimnya penelitian tentang kemandirian anak asuh panti asuhan, minimnya buku-buku tentang kemandirian anak asuh, dan minimnya seminar atau diskusi tentang kemandirian anak asuh panti asuhan yatim. Dalam tulisan ini anak yatim dan atau piatu disebut sebagai anak asuh panti asuhan.

Dengan dasar pertimbangan di atas, peneliti mencoba memulai ikut berpartisipasi dalam bidang kemandirian anak asun, yaitu dengan melakukan penelitian yang berhubungan dengan bagaimana mengoptimalkan usaha membentuk dan mengembangkan kemandirian anak asuh panti asuhan 
yatim. Harapan peneliti, keterlibatan para akademisi pada konstelasi kemandirian. anak asuh panti asuhan yatim akan memunculkan konstruk teori tentang pembentukan dan pengembangan kemandirian anak asuh panti asuhan yang mampu melahirkan anak-anak panti asuhan yatim menjadi pribadi yang mandiri, yang siap berlomba (fastabiqui khoirat) dalam membangun bangsa dan negara.

Peneliti berasumsi bahwa untuk membentuk dan mengembangkan kemandirian anak asuh, selain dengan mengembangkan pola asuh yang demokratis darl berbagai slsinya (Lukman dkk., 1999), juga dilakukan dengan mengembangkan hal yang lain. Faktor tingginya tingkat kompetensi interpersonal dan konsep diri positif anak asuh adalah merupakan faktor lain yang dapat membentuk dan mengembangkan kemandirian anak asuh. Atas dasar asumsi Inllah, peneliti bermaksud meneliti hubungan dan pengaruh kedua faktor di atas dengan kemandirian anak asuh. Apabila hasil penelitian iri menunjukkan adanya hubungan yang signifikan, maka penelitian ini membuka jalan 'lain' (yang melengkapi) dalam usaha mengoptimalkan usaha pembentukan dan pengembangan pribadi mandiri anak asuh panti asuhan (PAY).

\section{KEMANDIRIAN}

Penelitian tentang Kemandirian sejauh yang dapat peneliti dapatkan antara lain telah dilakukan oleh Nuryoto (1993), Djunanah (1999), Nashorl (1999) dan Lukman dkk. (1999). Nuryoto meneliti tertang hubungan antar peran jenis dengan kemandirian siswa SMU. Nuryoto menemukan antara lain tidak ada perbedaan antara kemandlrian antara remaja laki-laki dan perempuan. Djunanah meneliti tentang Pengaruh sikap penerimaan orang tua dan Kemandirian slswa SMU Uil Yogyakarta.
Hasil penelitian Djunanah menyebutkan adanya hubungan antara sikap penerimaan orang tua dengan kemandírian siswa SMU.

Nashori (1999) meneliti hubungan antara religiusitas dengan kemandirian siswa SMU. Hasil penelitlan menyebutkan adanya hubungan antara religiusitas dengan kemandirian. Lukman dkk. (1999) menelitl tentang hubungan model asuh dengan kemandirian dan kreativitas anak asuh. Penelitian Lukman dkk. ini menyimpulkan bahwa model asuh mempunyai peran yang sangat besar terhadap pembentukan dan pengem. bangan kemandirlan dan kreativitas anak asuh.

Pengertian Kemandirian. Kemandirian berasal dari kata mandiri yang berarti berdiri sendirl (Poerwodarminto, dalam Lukman dkk, 1999). Dari makna ini mandiri mempunyal pengertian tidak tergantung pada orang lain, a tauterpengaruh orang kin, serta melakukan aktivitas, inisiatif dan kreativitasnya sendíri.

Suyata (dalam Djunanah, 1999) mendefinisikan sikap kemandirian sebagai suatu keadaan personalistik yang bercirikan adanya kecenderungan determinasi dirl dalam kerangka dukungan soskal atau inner person with inner activies. Definisi ini mempunyal pengertlan bahwa sikap kemandirian seseorang merupakan kepribadian yang dimililj orang yang bersangkutan dalam dimensi sosial. Secara singkat definisi ini mempunyai pengertian bahwa individu mandiri adalah individu yang mampu menentukan diri, arah dan tindakannya dakam kerangka hubungan sosial.

Sementara Maslow (dalam Djunanah, 1999) mengemukakan bahwa kemandirian merupakan suatu karakteristik orang yang dengannya la dapat mengaktualisasikan dirinya, dan menjadi dirinya sendíri seoptimal mungkin.

Masih tentang kemandirian seseorang, ldrus (1999) mengungkapkan bahwa ke- 
mandirian seseorang tidak hanya ditandai dengan usia, tetapi salah satunya ditandai dengan perilakunya. Artinya, mungkin saja terjadi anak yang berusia lebih muda dapat lebih mandiri (untuk ukuran anak seusianya), sementara yang lebih tua belum tentu memiliki tingkat kematangan yang sama dengan yang dimiliki oleh yang tingkat usianya lebih muda. Sementara itu, Watson dan Lindgren (dalam Nuryoto, 1993) menyatakan bahwa tingkah laku mandiri meliputi pengambilan inislatif, mengatasi hambatan, melakukan sesuatu dengan tepat, glgih dalam usahanya dan melakukan sesuatu sendiri tanpa bantuan orang lain.

Darl beberapa pengertian d atas, dapat disimpulkan bahwa dalam sikap kemandirian terkandung; (1) kemandirian merupakan baglan darl kepribadian, (2) dapat menentukan dirf serta arah tindakannya, (3) adanya kecenderungan untuk memenuhl kebutuhannya sendirl, dan (4) dalam kerangka dukungan sosial.

Ciri-ciri sikap mandiri. Ciri-ciri sikap mandiri menurut beberapa ahli (dalam Djunanah, 1999) sebagal berikut; (a) memenuhi diri atau identitas diri, (b) memiliki kemampuan inisiatif, (c) membuat pertimbangan sendiri dalam bertindak, (d) mencukupl kebutuhan sendiri, (e) bertanggungjawab atas tindakannya, (i) mampu membebaskan dirl dari keterkatan yang tidak perlu, (g) dapat mengambll keputusan sendiri dalam bentuk kemampuan memilih. Idrus (1999) menambahkan ciri-ciri kemandirian sebagai berikut; (h) tekun, (i) percaya dirl, (0) berkeinginan mengerjakan sesuatu tanpa bantuan orang lain, (k) puas terhadap hasi usahanya sendiri, dan Masrun dkk. (1986) juga berpendapat bahwa; (l) Pengendalian diri juga masuk dalam ciriciri kemandirian.

Adapun faktor-faktor yang mempengaruhi kemandirian ada lima, yaitu; (a) keluarga; misalnya perlakuan ibu terhadap anak, (b) sekolah; misainya periakuan guru, dan teman sebaya, (c) mediakomunikasi massa; misalnya majalah, koran, televisi dan sebagainya, (d) agama; misalnya sikaptemadap agama yang kuat, (e) pekerjaan atau tugas yang menuntut sikap pribadi tertentu (Hurlock, dalam Djunanah, 1999).

Nuryoto (1993) mengungkapkan bahwa kemandirlan merupakain suatu kemampuan psikologis yang berkembang terus sampai akhir masa remaja, sejalan bertambahnya umur dan pengalaman-pengalaman vang diperolehsepanjang hidup meneka. Walaupun demikian, seperti diungkap oleh Idrus (1999), proses perkembangan kemandirian seseorang tidak ditandal dengan usia, tetapl salah satunya ditandai dengan perllakunya. Hal ini memungkinkan terjadl anak yang berusia lebih muda, tetapi sikap kemandiriannya lebih tinggi daripada anak yang berusia lebih tua.

Slkap kemandirian dalam ekspresinya yang berupa tingkah laku sehari-hari mengandung unsur-unsur emosi, kata hati, moral intelektual, sosial dan ekonomi. Unsur-unsur tersebut saling berkaitan erat dan sulit dipisahkan.

Sebagiamana kondisi psikologis yang lain, sikap kemandiran dapat berkembang balk apabila diberi kesempatan berkembang melalul latihan terus menerus. Latiha: tersebut dapat berupa pemberian tugas-tugas yang sesuai dengan umur anak yang bersangkutan dengan tanpa bantuan. Dengan latihan terus menerus ini akan tumbuh sikap kemandirian dalam diri anak, yang pada gilirannya sikap kemandirian tersebut akan mampu menghadapi permasalahan yang kompleks dan berani menghadapi tantangan hidup. Sikap kemandirian yang berakar kuat dalam diri seseorang akan membuat anak tersebut tangguh, tidak mudah diombangambingkan keadaan, dan mampu memecahkan masalah dengan tanpa bantuan orang lain. 


\section{KOMPETENSI INTEAPERSONAL}

Penelitian kompetensi interpersonal, sejauh yang peneliti dapatkan informasinya antara lain dilakukan oleh Danardono (1997), dan Mulyati (1997), dan Fuad Nashori (2000). Nashori (2000) meneliti tentang hubungan kematangan beragama dengan kompetensi interpersonal mahasiwa. Dari hasil penelitian Nashori terse but ditemukan bahwa ada hubungan yang signifikan antara kematangan beragama dengan kompetensi interpersonal mahasiswa. Penelitian sebelumnya tentang kompetenși interpersonal dilakukan oleh Danardono (1997). la meneltiti tentang kompetensi interpersonal mahasiswa ditinjau dari keikutsertaan pada kegiatan pecinta alam. Hasinya, mahasiswa yang aktif dalam keglatan kepencintaalaman memiliki kompetensi yang lebh tinggi (signifikan) daripada mahasiswa yang tidak aktif dalam keglatan Kepencitaalaman. Sedangkan Mulyati (1997) meneliti tentang kompetensi interpersonal pada anak panti asuhan dengan sistem pengasuhan tradisional dan anak panti asuhan dengan sistem kepengasuhan lbu asuh. Hasilnya, tidak ada perbedaan antara keduanya.

Pengertian Kompetensi Interpersonal. Sebelum peneliti mengemukakan tentang pengertian kempetensi interpersonal secara lengkap, terlebih dahulu peneliti akan mengemukakan pengertian kompetensi. Menunt Sears dkk. (1994), kompetensi adalah kemampuan yang biasanya pemiliknya lebh dihargai untuk diajak menjalin hubungan daripada orang yang tidak berkemampuan. Artinya, kompetensi adalah merupakan kecakapan atau kemampuan yang dihargai oleh orang lain.

Dari pengertian tersebut, peneliti menyimpukan bahwa kompetensi interpersonal adalah kemampuan atau kecakapan yang mendukung hubungan antara individu dengan individu lainya. Hubungan antara individu denganindividu kainnyamempunyaipengertian bahwa hubungan tersebut terbatas pada satu Individu dengan individu, bukan hubungan antara individu dengan orang banyak atau masyarakat sosial pada umumnya.

Lebih terperincl mengenai pengertian kompetensi interpersonal ini, Nashori (2000) mengemukakan bahwa kompetensi interpersonal adalah kemampuan untuk melakukan hubungan antar pribadl secara efektif. Hal ini ditandal oleh adanya karakteristik-karakteristik psikologis yang mendukung dalam menciptakan dan membina hubungan antar pribadi yang baik dan memuaskan.

Adapun aspek kompetensi inteppersonal, menurut Buhrmester dkk. (1988; dalam Mulyati, 1997) meliputi lima hal yaitu; (a) Kemampuan berinisiatif dalam memulai suatu hubungan interpersoanal, (b) kemampuan untuk membuka diri (self Dlsclosure), (c) Kemampuan untuk bersikap asertif, (d) kemampuan untuk memberi dukungan emosional, dan (e) kemampuan untuk mengelola dan mengatasi konflik-konflik yang timbul dalam hubungan interpersonal.

Kemampuan Berinisiatif. Secara lebih terperincl, yang dimaksud dengan Kemampuan berinisiatif dalam memulal suatu hubungan interpersonal adalah kemampuan untuk memulaj suatu usaha untukberinter aksi dengan orang lain. Pengertian ini menunjukkan bahwa kemampuan berinsiatif membuka hubungan (berinteraksi) dengan orang lain adalah kemampuan yang dipengaruhi oleh bagaimana individu bersangkutan mampu membuka hubungan dengan individu yang lain. Jalaluddin Rakhmat (1998) mengungkapkan bahwa hubungan interpersonal berlangsung melewati tiga tahap, yaitu tahap pembentukan hubungan, peneguhan hubungan dan pemutusan hubungan. Kemampuan berinisiatif membuka hubungan pada aspek yang pertama inilah yang dimaksud dengan tahap pertama dalam hubungan interpersonal, yaítu tahap perkenalan. 
Steve Duck (dalam Rakhmat, 1998) berpendapat bahwa:

... perkenalan adalah proses komunikasi di mana individu mengirimkan (secara sadar) atau menyampaikan (kadang. kadang tidak sengaja) informasi tentang struktur dan isi kepribadiannya kepada bakal sahabatnya, dengan menggunakan cara-cara yang agak berbeda pada bermacam-macam rahap perkembangan persahabatan."

Kemampuan bersikap terbuka. Yang dimaksud dengan kemampuan untuk bersikap terbuka (self disclosure) adalah kemampuan seseorang untuk mengungkap informasi yang bersifat pribadi mengenai dirinya dan memberikan perhatian kepada orang lain. Pengungkapan informasi pribadi ini adalah suatu bentuk penghargaan yang akan memperluas kesempatan terjadinya sharing.

Sementara Rakhmat (1998) dengan mengutip pendapat Brooks dan Emmert mengungkapkan bahwa sikap terbuka yang mempunyai pengaruh besar terhadap hubungan interpersonal (komunikasi interpersonal) adalah; (a) menilai pesan secara obyektif, yaitu dengan menggunakan data dan keajegan logika, (b) dapat membedakan dengan mudah, (c) melihat nuansa, (d) berorientasi pada isi, (e) mencari informasi dari berbagai sumber (f) lebih bersifat profesional dan bersedia mengubah kepercayaannya, (g) mencari pengertian pesan yang tidak sesuai dengan rangkaian kepercayaannya.

Dari pengertian dan kedua pendapat di atas dapat dirumuskan bahwa sikap terbuka (self disclosure) merupakan kemampuan untuk membuka din, menyampakan informasi yang bersifat pribadi, menghargai orang lain, menilai informasi secara obyektif dengan menggunakan data dan logika, dapat menangkap pesan dengan mudah, berorientasi pada isi, bersikap rasional can proporsional, dan konfirmasi mengenai hal yang belum diketahuinya.

Kemampuan untuk bers!kap asertif. Menurut Perlman dan Cozby (1983; dalam Mulyati, 1997), asertivitas adalah kemampuan dan kesediaan individu untuk meng ungkap perasaan-perasaannya secara jelas dan dapat mempertahankan hak-haknya dengan tegas. Sedangkan Calhoun dan Acocela (dalam Nashori, 2000) berpendapat bahwa asertivitas adalah kemampuan untuk meminta orang lain untuk melakukan sesuatu yang dlinginkan atau menolak untuk. melakukan hal yang tidak diingingkan.

Kemampuan memberikan dukungan emosional. Memberi dukungan emosional di sini berarti memberi dukungan yang bersifat afektif. Memberi dukungan afeksi yang salah satu bentuknya (ekspresinya) adalah empati. Kartini Kartono dan Dali Gulo (1987) berpendapat bahwa empati adalah kemampuan untuk memahami perasaan orang lain. Perasaan ini akan diterima orang lain sebagai sikap yang hangat, yang mana hal ini adalah merupakan dasar penting bagi tumbuhnya sikap menolong. Orang memiliki sifat empatik yang tinggi berarti memiliki keinginan menolong yang tinggi. Pertolongan inilah yang akan membuat hubungan interpersonal menjadi semakin erat.

Selain pendapat di atas, Buhrmester ckk (dalam Nashori, 2000) juga berpendapat bahwa dukungan emosional mencakup kemampuan untuk menenangkan dan memberi rasa nyaman kepada orang lain ketika orang tersebut sedang dalam keadaan tertekan dan bermasalah.

Dari beberapa pendapat $\&$ atas dapat dirumuskan bahwa kemampuan memberi dukungan emosional adalah kemampuan untuk mengekspresikan perhatian, kesabaran, simpati, kebersediaan menolong, memberi rasa nyaman kepada orang lain.

Kemampuan dalam mengatasi konflik. Peterson (dalam Sears dkk., 1994) ber- 
pendapat bahwa kontik adalah suatu proses yang terjadi bila perilaku seseorang terhambat karena perilaku orang lain. Sedangkan konflik merupakan suatu hal yang wajar terjadi dalam hubungan antar individu, bahkan pada hubungan yang dirasa sangat sempurna pun konflik tetap mungkin bisa terjadi. Bahkan bisa dikatakan bukan hubungan yang sempurna bila tidak pernah terjadi konflik. Grasha (dalam Nashori, 2000) mengatakan bahwa konflik akan selalu ada dalam setiap hubungan antar manusia dan bisa disebabkan berbagai hal. Lebih lanjut ia mengemukakan bahwa konflik dapat disebabkan oleh ketegangan yang meningkat antara individu yang disebabkan oleh adanya keinginan yang salaing bertentangan antara satu dengan yang lain.

Mengingat potensi konflik yang selalu ada dalam hubungan antar individu, maka kemampuan mengatasi konflik adalah kemampuan yang mutlak diperlukan- oleh setiap individu yang menjalin hubungan dengan individu yang lain. Menurut Nashori (2000), kemampuan mengatasi konflik ini diperlukan agar tidak merugikan suatu hubungan yang terjalin karena akan memberikan dampak negatif bila tidak terselesaikan dengan bak. Konflik dapa menunjarg maupu mengancam suatu hubungan, tergantung bagaimana menyikapi konflik tersebut.

Kemampuan mengafasi konflik meliputi sikap-sikap unfuk menyusun strafegi penyelesaian masalah, mempertimbangkan kembal penilaian atas suafu masalah dan miengembangkan konsep harga diri yang baru. Menyusun strategi penyelesaian masalah adalah bagaimana individu yang bersangkutan merumuskan cara untuk menyelesaikan konflik dengan sebaik-baiknya. Kemudian disusul dengan mempertimbangkan masakh yang menjadi pemicu konflik secara obyektif, rasional dan proporsional. Selanjutnya adalah konsekuensi dari pertimbangan masalah tersebut, yaitu mau mengakui dari mana masalah tersebut muncul dengan mengembangkan konsep harga diri yang baru.

\section{KONSEP DIRI}

Beberapa penelitian tentang konsep diri yang peneliti dapatkan informasinya antara lain, penelitian dilakukan oleh Saam dan Ancok (1989), Partosuwido (1993), Helmi (1995), Andayani dan Alfiatin (1996). Saam dan Ancok meneliti tentang korelasi antara konsep diri multidimensional dan prestasi akademis. Penelitian ini menemukan adanya korelasi yang positif dan signifikan antara dimensi-dimensi konsep diri dan prestasi akademis. Partosuwido meneliti tentang penyesuaian diri mahasiswa dalam kaitannya dengan konsep diri, pusat kendali dan status perguruan tinggi. Helmi menelíti tentang konsep diri, harga diri dan ke percayaan diri remaja.

Pengertlan konsep dirl. Rakhmat (1998) dengan merujuk pendapat William D. Brooks (1974) berpendapat bahwa konsep diri adalah pandangan dan perasaan kita fertang diri kita. Lebih lanjut (1998) mengemukakan bahwa konsep diri bukan saja gambaran deskriptif tentang diri kita, namun juga penilaian atas diri kifa. Artinya, konsep diri meliputi apa yang kita pikirkan dan apa yang kita rasakan tentang diri kita.

Secara lebih terperinci, Rakhmat (1998) merumuskan beberap pertanyaan berkaitan dengan konsep diri ini, yaitu:

a. Bagaimana watak saya sebenarnya?

b. Apa yang membuat saya bahagia atau sedih?

c. Apa yang sangat mencemaskan saya?

d. Bagaimana orang lain memandang saya?

e. Apakah mereka merendahkan atau menghargai saya?

f. Apakah mereka membenci atau menyukai saya? 
g. Bagaimana pandangan saya tentang penampilan saya?

h. Apakah saya orang cantik atau jelek?

i. Apakah tubuh saya kuat atau lemah?

Seide dengan Jalaluddin Rakhmat adalah

Rosenberg (dalam Partosuwido, 1993) mengemukakan bahwa konsep diri adalah struktur mental, suatu totalitas dari pikiran, dan perasaan dalam hubungannya dengan diri sendiri. Sedangkan Markus dan Wurt (dalam Partosuwido, 1993) memberi batasan konsep diri sebagai komponen yang dinamis dan multi dimensional dalam sistem afektif dan kognitif pada seseorang yang mengarahkan perilaku.

Konsep diri ini selain merupakan gambaran dan deskripsi tentang diri sendiri juga merupakan hasil penilaian terhadap diri sendiri. Konsep ini dikemukakan oleh Malcom dan Steve Heyes (1985). Menurut mereka konsep diri adalah merupakan gabungan dari Citra diri (self image) dan Harga diri (self esteem). Citra diri merupakan bagian deskripsi sederhana; misalnya, saya seorang pelajar, saya seorang kakak, saya seorang pemain bulutangkis, tinggi saya $160 \mathrm{~cm}$ dan sebagainya. Sedangkan Harga diri meliputi suatu penilaian, suatu perkiraan, mengenai pantas diri (self wort); misalnya, saya peramah, saya agak pandai dan sebagainya. Robins (1996) mengenai harga diri mengungkapkan bahwa seseorang berbeda dalam derajat sejauh mana mereka menyukai atau tidak menyukai dirinya.

Thalib (1996) memberikan pengertian konsep diri adalah pandangan, pemikiran dan perasaan seseorang mengenai dirinya sendiri. Menurutnya, perbedaan para ahli dalam meberikan pengertian tentang konsep diri bukan pada dataran prinsipil, hany a pada aspek-aspeknya saja.

Dari pendapat-pendapal tentang konsep dirl di atas, peneliti merumuskan bahwa konsep diri adalah pendapat atau gambaran dan penilaian kita tentang diri kita sendiri, yang meliputi mental, pikiran dan perasaan

Struktur konsep dirl.Saam dan Ancok (1989) mengemukakan bahwa struktur konsep diri secara hierarkis terdiri dari empat peringkat, yaitu; (a) konsep diri umum, yaitu cara individu memehami dirinya secara keseluruhan, (b) konsep diri akademis dan non akademis, (c) sub area dari konsep diri akademis dan non akademis, dan (d) penilaian dari tingkah laku spesifik dari masingmasing sub area dari konsep diri. Berbeda dengan Saam dan Ancok, Pudjijogyanti (dalam Nashori, 2000) berpendapal bahwa secara hierarkis konsep diri terdiri dari tiga, yaitu konsep diri umum, mayor dan spesifik.

Peneliti lebih cenderung sepakat dengan pendapat Thalib (1996) yang menyimpulkan bahwa aspek-aspek konsep diri meliputi; (a) konsep diri akademis, (b) konsep diri fisik, (c) konsep diri pribadi, (d) konsep diri sosial, (e) konsep diri etik, (f) konsep diri keluarga. Kesimpulan Thalib in secara tersirat cukup akomodatif dari perbedaan yang dikemukakan oleh para ahli

Proses terbentuk dan perkembangan konsep diri. Thalib (1996) berpendapat bahwa konsep diri terbentuk dan berkembang dipengaruhi oleh pengalaman ałau kontak ekstemal dengan lingkungannya dan juga pengalaman intemal tentang dirinya. Pengalaman internal ini akan mempengaruhi respon terhadap pengalaman eksternalnya. Dari kedua faktor tersebut terbentuklah konsep diri. Tidak jauh berbeda dengan pendapat Thalib tersebut, Saam dan Ancok (1989) berpendapat bahwa konsep diri berkembang karena ada proses interaksi dirinya dengan individu atau kelompok lain.

Secara dinamis, konsep diri terbentuk dan berkembang karena adanya pengalaman interaksi antara dirinya dengan orang lain. Dasar pengalaman dan interaksi ini kemudian individu menilai dirinya dan gilirannya menggunakan penilaian tersebut meniadi tolok ukur dalam berpikir dan berperilaku. 
Hurlock (1996) berpendapat bahwa terbentuknya konsep diri melalui tiga jenjang, yaitu;

1. Konsep Diri Primer, konsep diri ini terbentuk dari pengalaman-pengalaman sosial anak di rumah sejak umur umur awal.

2. Konsep Diri Sekunder; Terbentuk saat interaksi dengan lingkungan di luar keluarga, seperti teman-temannya.

3. Konsep Diri Ideal; konsep diri ini terbentuk karena adanya hubungan yang lebih erat daripada sebelumnya.

Lebih terperinci, Hurlock (1996) mengemukakan 12 faktor yang mempengaruhi perkembangan konsep diri, yaitu fisik, tempo kematangan biologis, sikap terhadap anggota keluarga, harapan orang tua, sikap terhadap teman sebaya, masalah pribadi atau Keluarga, masalah ekonomi keluarga, sekolah. pendapat teman sebaya, agama, kesempatan sekolah, dan pengaruh radio, televisi dan lain-lain.

Pengaruh konsep diri dalam ke hidupan sosial. Penelitian yang dilakukan oleh Helmi dan Ramdhani (1992), Murdoko (1994), Partosuwido (1992), Sulistyani (1990) dan Suparni (dalam Andayani dan Alfiatin, 1996) menunjukkan bahwa konsep diri sangat penting bagi keberhasilan individu dalam hubungan sosialnya. Artinya, konsep diri yang positif akan membawa pemiliknya berperilaku yang positif, begitu pula sebaliknya.

Upaya perubahan konsep diri, menu'ut Pudjijogyanti (dalam Thalib 1996) bisa dilakukan dengan mengubah lingkungan sosialnya. Ha ini mengingat konsep diri tidak hanya terbentuk dari pengalaman internal individu, namun juga dipengaruhi oleh pengalaman ekstemal individu.

\section{HUBUNGAN ANTARA KOMPETENSI INTERPERSONAL DAN KONSEP DIRI DENGAN KEMANDIRIAN}

Hubungan Antara KompetensI Interpersonai dan Kemandirian. Kompetensi Interpesonal sebagai suatu kemampuan yang mendukung individu dalam membina dan mempertahankan hubungan dengan individu lain adalah merupakan kemampuan yang membuat pemiliknya dihargai orang lain. Dengan kemampuan ini, seseorang dapat memulai, membina dan mempertahankan hubungannya dengan orang lain.

Dalam kehidupan dewasa ini terlihat bahwa kesuksesan tidaklah dapat ditempuh sendiri. Artinya, sebagai makhluk sosial mau tidak mau seseorang dalam menempuh kehidupan ini harus berhubungan dengan orang lain. Karena adanya keharusan berhubungan dengan orang lain inilah, maka seseorang yang berkepribadian mandiri pun harus mempunyai kemampuan interpersonal untuk membina dan mempertahankan hubungannya dengan orang lain. Hal ini dikemukakan juga oleh Maslow (dalam Goble, 1994) bahwa individu yang sangat mandiri adalah individu yang sehat secara psikologis, yang dirasakan oleh masyarakat lingkungannya sebagai orang yanmg individualis sekaligus sosiawan, paling bersahabat serta paling cinta kepada sesama.

Berawal dari pertanyaan inilah, peneliti berasumsi bahwa pada dasarnya kemandirian mempunyai hubungan yang erat dengan kompetensi interpersonal. Secara teoritis, hubungan antara kemandirian dengan kompetensi interpersonal Ini dapat dibuktikan dengan mengamati aspek-aspek kemandirian dan kompelensi interpersonal. Dalam aspek kemandirian terdapat aspek yang erat hubungannya dengan keman. dirian, yaitu kemampuan berinisiatif, dapat mengambil keputusan sendiri dalam bentuk kemampuan memilih, mengendalikan diri, mampu membebaskan diri darl keterikatan 
yang tidak perlu dan percaya diri. Aspekaspek tersebut juga menjadi bagian dari aspek-aspek kompetensi interpersonal, seperti inisiatif dalam memulai berkenalan atau berhubungan, terbuka dan dapat menyelesaikan konltik yang berarti proses me milih, mengatasi korflik yarg berarti tindakar: tindakan pengendalian diri dan melepaskarı dari keterikatan yang tidak perlu.

Hubungan Antara Konsep Diri dengan Kemandirian. Hubungan secara teoritis artara konsep diri dengan kemandirian tersetak pada kemampuan konsep diri yang positif, baik dalam aspek fisik, sosial, pribadi, moral dan keluarga yang amat berpengaruh pada pembentukan perilaku. Apabila individu meriganggap dirinya adalah individu yarı lemah, maka kapan la akan bertindak, apalagi melangkah sendiri (mandiri).

Hubungan konsep diri dengan kemandiriar! pada salah satu aspek yang yang sangat penting dalam mendukung terbentukrya kemandirian individu, yaitu sikap percaya diri. Hal ini dikarenakan tanpa adanya korısep diri yang positif, maka sangat sulit atau bahkan tidak pemah seseorang dapat mempunyai kepercayaan diri yang kuat, padahal dalam pembentukan dan pengembangan sikap mandiri, percaya diri adalah salah satu hal yang mutlak.

Huburigan Antara Kompeterisi Irterpersonal darı Konsep Diri dengan Kemandirian Dari hubungar masing-masing variabel bebas dengan kemaridian tersebut, secara teoritis terdapa: hubungan yang signifikan. Hubungan ini dapat dicermati dari aspekaspek variabel tersebut yang saling bersinggurigan. Aspek-aspek tersebut adalah percaya diri dari kemanditian, konsep diri pada sub aspek kompetensi interpersonal.

Usaha Optimalisasi Strategi Pengembangan Kemandirian Anak yatim.Sebagaimana telah diungkap pada latar belakang penelitian ini, bahwa penelitian ini adalah merupakan 'jalan lain' dalam usaha mengembangkan kemandirian anak yatim darı atau piatu. Maksudrya, jika penelitian ini meruunjukkan hubungan yang signifikan seperti pada kajian teoritis di atas, maka kemungkinan untuk mengembangkan kemandirian anak yatim darı atau piatu melalui pengembangar kompetensi interpersonal dan konsep diri semakin terbuka.

Selama ini kemandirian anak asuh panti asuhan identik dengan model pengasuhan panti asuhan. Model asuh panti asuhan sangat mempengaruhi tinggi dan rendahnya kemandirian anak asuh. Perelitian pada gilitannya akan membuka cakrawala lain bahwa kemandirian anak asuh dapat dikembangkar melalui pengembangan kompetensi interpersorial dan konsep diri. $\mathrm{Hal}$ ini akan memberi keuntungari ganda pada usaha pengembangan kemandirian anak asuh, yaitu selain merigembangkan kemandirian anak asuh sekaligus mengembarigkan kompetensi iriterpersonal darı korisep diri anak asuh panti asuhan.

Pengembangan kemandirian melalui kompetensi interpersonal dan konsep diri, dapat dikembangkarı melalui pelatihan dan pengkondisian lingkungan. Selain itu, peneliti berasumsi bahwa pengembangan kemandirian melalui pengembangan kompeterısi interpersonal dan konsep diri dapat juga digarap melalui pengembangan materi keagamaan yang tidak hanya bersitat melangit, akan tetapi dengan pengembarngan wacana keagamaan yang bersifat membumi dan bersentuhar derigan konsep kompetensi interpersonal dan konsep diri.

\section{HPOTESIS}

Dalam penelitian ini diajukan hipotesis sebagai berikut:

1. Terdapat hubungan ganda yang signifikan antara kompeterisi interpersonal dan konsep diri dengarı kemandirian anak asuh. 
2. Terdapat hubungan signifikan antara kompetensi interpersonal dengan kemandirian dengan mengontrol variabel konsep diri.

3. Terdapat hubungan signifikan àntara konsep diri dengan kemandirian anak asuh dengan mengontrol variabel kompetensi iterpersonal.

\section{MET ODE}

Subjek penelitian ini adalah anak asuh panti asuhan yatim Islam di Kota Yogakarta yang berusia remaja (1.3-21 tahun). Menurut data yang peneliti peroleh dari Dinas Sosial menyebutkan bahwa panti asuhan yakim Islarn d Kota Yogyakarta ada empat panti asuhan, yaitu panti asuhan yatim Putra Islam, panti asuhan putra Muhammadiyah, panti asuhan yatim Putri Isiam dan panti asuhan yatim Putri Aisyiyah. Namun, di lapangan menunjukkan bahwa panti asuhan yatim Putra Islam sudah pindah tempat ke daerah Berbah Sleman. Jadi penelikian ini di lakukan di tiga tempat, yaitu panti asuhan yatim Putri Islam, panti asuhan yatim Putri Aisyiyah dan panti asuhan putra Muhammadiyah.

Teknik pengambilan sampel dilakukan dengan menggunakan teknik Simple Random Sample. Artinya, anak asuh panti asuhan yatim Islam yang berusia remaja mendapat kesempatan yang sama untuk menjadi sampel. Besar sampel dalam penelitian ini menggunakan acuan Tabel Kricje. Menurut tabel tersebut (dalam Sugiyono, 1999) dengan jumlah populasi sebebsar 102 anak, maka sampel yang harus diambil paling tidak bejumlah $81-82$. Dalam penelitian ini direncanakan mengambil 85 subjek.

Pengambilan data dilakukan dengan menggunakan metöde angket. Sikap kemandirian diambil dengan menggunakan angket Kemandirian, kompetensi interpersonal diambil dengan Angket Kompetensi
Interpersonal, dan konsep diri diambil dengan Angket Konsep Diri. Mengingat penelitian dengan tiga variabel dengan populasi anak asuh panti asuhan adalah baru, maka peneliti menyusun sendiri angket ketiga variabel tersebut.

Angket Kemandirian peneliti susun berdasarkan aspek-aspek sebagai berikut: memenuhi diri atau identitas diri, memiliki kemampuan inisiatif, membuat pertimbangan sendiri dalam bertindak, mencukupi kebutuhan sendiri, bertanggungjawab atas tindakannya, mampu membebaskan diri dari keterikatan yang tida perlu, dapat mengambil keputusan sendiri dalam bentukmemilih, tekun, percaya diri, berkeinginan mengerjakan sesuatu dengan tanpa bantuan orang lain, puas terhadap hasi usahanya sendiri dan mampu mengendalikan diri.

Angket Kompetensi interpersoal peneliti susun berdasarkan lima aspek, yaitu; inisiatif, keterbukaan, asertivitas, dukungan emosional, dan kemampuan mengelola konflik, Angket Konsep Diri peneliti susun berdasarkan enam aspek, yaiku konsep diri akademis, konsep diri fisik, konsep diri sosial, konsep diri pribadi, konsep diri mora etik dan konsep diri keluarga (asrama, karena dalam asrama panti asuhan).

Angket Kemandirian setelah diujicobakan dengan menggunakan 42 aitem tidak memenuhi standar minimal validitas dan reliabilitas instrumen, Karena terlalu rendahnya reliabilitas dan daya beda, maka peneliti mengubah angket kemandirian menjadi 36 aitem. Setelah diujicokan, 36 butir tersebut menghasilkan reliabilitas sebesar 0,851 dan koefisien korelasi aitem-total bergerak antara 0,118 sampai 0,713 . Penelti kemudian mengambil 22 butir dari 36 tersebut dengan tetap mempertimbangkan aspek-aspek kemandirian. Angket yang ketiga ini mempunyai reliabilitas sebesar 0,870 dan koefisien korelasi aitem-total bergerak antara 0,246 sampai 0,641 . 
Angket Kompetensi interpersonal setelah diujicobakan dengan jumlah aitem 64 tidak memenuhi standar minimal korelasi aitem-total yang merupakan salah satu indikator validitas, maka istrumen ditambah menjadi 72 butir dan diujicobakan kembali. Ujicoba kedua ini menghasilkan reliabilitas sebesar 0,800 dan koefisien korelasi aitemtotal bergerak dari -462 sampai 0,625. Dari 72 butir tersebut, peneliti mengambil 42 butir untuk dijadikan instrumen jadi. Ke 42 butir tersebut mempunyal reliabilitas sebesar 0,924 dan koefisien korelasi aitem-total bergerak antara 0,210 sampal 0,768 .

Angket Konsep Diri dengan jumlah 44 butir diujicobakan dan memperoleh reliabilitas sebesar 0,875 dan koefisien korelasi aitem-total bergerak antara $-0,274$ sampai 0,759. Dari 44 butir tersebut dipilih 34 butir yang memenuhl standard minimal. 34 butir tersebut mempunyai reliabilitas sebesar 0,917 dengan koefislen korelastaitem total bergerak antara 0,258-0,783.
Untuk menguji hipotesis yang dajukan akan dlgunakan teknik statistik regresi ganda dan teknik statistik korelasi parsial. Kedua teknik statistik ini df igunakan dengan bantuan jasa program SPSS for Windows.

\section{HASIL.}

Subjek yang mengisi angket berjumlah 85 anak asuh, namun karena ada tlga subjek yang tidak sesuai dengan kategori subjek dan tidak lengkap dalam mengisi angket, maka ketiga angket tersebut tidak dipakai. Dari 82 subjek terdapat 39 anak asuh laki-laki dan 43 anak asuh perempuan dengan rentang umur antara 13 sampai 19 tahun.

Data yang dlperoleh menunjukkan bahwa sikap kemandirian, kompetensi interpersonal dan konsep diri, masing-masing sebagai berikut:

Tabel 1

Rentang Skor Hasfl Ponelttan Skkap Kemadirlan

\begin{tabular}{|l|l|c|c|c|}
\hline No. & Kompetensi Inter. & Skor & Jumlah & Persentase \\
\hline 1 & Tinggi & $93 \cdot 110$ & 2 & $2,4 \%$ \\
2 & Sedang & $39 \cdot 92$ & 80 & $97,6 \%$ \\
3 & Rendah & $22-38$ & 0 & $0 \%$ \\
\hline
\end{tabular}

Tabel 2

Rentang Skor Hasll Penelltan Kompetensf Interpersonat

\begin{tabular}{|l|l|l|l|l|}
\hline No. & Kompetensi Inter. & Skor & Jumlah & Persentase \\
\hline 1 & Tinggi & $168 \cdot 220$ & 4 & $4.8 \%$ \\
2 & Sedang & $85 \cdot 167$ & 78 & $95,2 \%$ \\
3 & Rendah & $44-84$ & 0 & $0 \%$ \\
\hline
\end{tabular}




\section{Tabel3 \\ Rentang Skor Hasil Penelitian Konsep Diri}

\begin{tabular}{|c|l|c|c|c|}
\hline No. & \multicolumn{1}{|c|}{ Konsep diri } & Skor & Jumlah & Persentase \\
\hline 1 & Tinggi & $137-170$ & 1 & $1,2 \%$ \\
2 & Sedang & $68-136$ & 81 & $98,8 \%$ \\
3 & Aendah & $34-67$ & 0 & $0 \%$ \\
\hline
\end{tabular}

Sebelum melakukan uji korelasi ganda dan korelasi parsial, dilakukan terlebih dahulu uj asumsi, yaitu normalitas sebaran, uji linearitas dan uji kolinearitas. Dari data yang diperoieh ( $\mathrm{N}=82$ ), masing-masing menunjukkan: Kemadirian mempunyai K-S$Z$ sebesar 0,948 dengan $P=0,330$; kompetensi interpersonal mempunyai K-S$Z$ sebesar 1,230 dengan $p=0,0970$; konsep dii mempunyai K-S-Z sebesar 0,667 dengan $\mathrm{p}=0,763$. Pertitungan Kolmogorov-Smimov ini menunjukkan bahwa data berdistribusi normal berikut:

\section{Tabel4}

Hasii Ui Linearitas $(N=82)$

\begin{tabular}{|l|l|l|}
\hline Variabel & Signifikansi & Keterangan \\
\hline Kompetensi - Kemandirian & 0.000 & Sangat linear \\
Konsep Diri - Kemandirian & 0.000 & Sangat linear \\
Kompetensi - Konsep Diri & 0.000 & Sangat linear \\
\hline
\end{tabular}

Hasil uji linearitas di atas menunjukkan bahwa semua data yang didapat adalah linear, namun terjadi pelanggaran asumsi, yaitu kolinearitas antara kompetensi interpersonal dengan konsep diri. Oleh karena itu, analisis Koreiasi Ganda dan Korelasi Parsial tidak dapat dilakukan. Analisis selanjutnya yang digunakan adakh korelasi sederhana antara kompetensi interpersonal dengan kemandirian dan konsep diri dengan kemandirian. Teknik statistik yang digunakan adalah korelasi product moment Pearson.

Hasil analisis korelasi sederhana sebagai berikut;

Tabel5

Hașli Anailsis Korelasi Product Moment $(M=82)$

\begin{tabular}{|l|c|c|}
\hline \multicolumn{1}{|c|}{ Korelasi } & $\mathbf{r}$ & $\mathbf{p}$ \\
\hline Kompetensi Interpersonal - Kemandirian & 0,600 & $p<0,05$ \\
Konsep Diri - Kemandirian & 0,592 & $p<0,05$ \\
\hline
\end{tabular}


Hasil tersebut menunjukkan adanya hubungan yang positif dan signifikan antara kompetensi interpersonal dengan kemandirian dan ada hubungan yang positif dan signifikan antara konsep diri dengan kemandirian.' Hal ini menunjukkan semakin tinggi kompetensi interpersonal anak asuh, maka semakin tinggi sikap kemandirian. Semakin tinggi konsep diri anak asuh, maka semakin tinggi sikap kemandirian.

\section{PEMBAHASAN}

Hasil penelitian Ini tidak sesuai dengan hipotesis yang diajukan. Hal ini disebabkan terjadi kolinearitas yang menghalangi dilakukannya analisis regresi ganda dan korelasi parslal. Namun dengan hasil penelitian ini, yaitu terbukti adanya hubungan yang positif dan signifikan antara kompetensi interpersonal dengan kemandirian dan adanya hubungan yang positit dan signifikan antara konsep diri dengan kemandirian, menunjukkan bahwa kompetensi interpersonal dan konsep diri masing-masing dapat dijadikan prediktor bagi sejauh mana kemandirian anak asuh panti asuhan yatim.

Dinamika psikologis hubungan antara kompetensi interpersonal dengan kemanditian dain konsep dirl sebagai berikut; kalau anak asuh pantl asuhan yatim memillki memilikı। kompetensi interpersonal dan konsep diri yang tinggi, maka ia punya kemandirian tinggi, begitu juga sebaliknya, apabila anak asuh mempunyal kemandirian yang rendah, maka kompetensi interpersonal dan konsep diri anak asuh juga yang rendah, maka la memiliki kemndirian rendah.

Secara lebih detail, hasil penelitian yang juga menunjukkan bahwa kemandirian. kompetensi interpersonal dan konsep diri anak asuh panti asuhan adalah sedang sebagai berikut:

Sikap Kemandirian. Sikap kemandirian anak asuh dalam kategori sedang disebab- kan oleh kepercayaan diri dan inisiatif yang kurang tinggi yang mempengaruhi skkap kemandirian secara total. Inisiatif yang kurang tingg dsebabkan oleh kondisi asrama yang walaupun telah membuka peluang anak asuh untuk berinisiatif, namun anak asuh mempunyal pand angan díri yang kurang positif mengenal inisiatif. Pandangan ini disebabkan oleh penilaian internal anak asuh terhadap diri mereka sebagai orang menerima 'terus', sehingga kalau akan berinisiatif akan muncui pertanyaan: mengapa saya rewel? Apa posisi saya? Slapa saya? dan seterusnya.

Sikap kemandiran anak asuh panti asuhan disebabkan oleh kondsi internal anak asuh sendiri, mampukah anak asuh membangun rasa percaya dirinya? Dalam membangun kepercayaan diri bukanlah hai yang mudah, apalagi daiam kondisi sosial dan ekonomi akhir-akhir ini. Kesulitan membangun rasa percaya dlri ini dlkarenakan tergambar secara jelas bagaimana banyaknya pengangguran dan kesulitan hidup di hadapan anak asuh. "Banyak anak yang tidak yatim gagal, bagaimana dengan saya yang 'hanya' anak yatim?" Pertanyaan ini sering mengganggu dan melemahkan kepercayaan dirl, apalagi kalau keyakinan dan ketawakkalan indivldu yang bersangkutan kepada Allah SWT Iemah.

Membangun keyakinan diri, menurut peneliti dapat dibangun melalui dua jalan; jalan yang pertama adalah dengan menginternalisasikan dan sekaligus meyakinkan bahwa mereka adalah anak-anak yang mampu. Jalan kedua adalah dengan sikap lingkungan yang menghargainya. Jalan pertama secara praktis dapat dilakukan secara efektif melalui peranan senior, pernbina, guru, ustadz dan pengasuh anak yatim dalam menginternalisasikan mis। membangun kepercayaan.

Kompetensi Interpersonal. Menurut pengamatan peneliti, kompetensi interper- 
sonal anak asuh pada dataran sedang disebabkan faktor inisiatif yang kurang tinggi pada anak asuh. Pembahasan tentang faktor inisiatif ini sebagaimana pada faktor inisiatif sikap kemandirian. Peneliti berpendapat bahwa guna membangun kompetensi interpersonal anak asuh panti asuhan yatim, harus menghilangkan pertanyaan imajiner anak asuh sebagaimana di atas. Menghapus pertanyaan imajener yang berawal dari 'ketidakbenaran' kalau ia berinisiatif adalah dengan mengembangkan sikap objektif dan proposional dalam kegiatan formal dan non formal.

Konsep Diri. Secara internal anak asuh panti asuhan yatim berpotensi untuk berkonsep diri cenderung negatif. Hal ini berkaitan dengan keberadaan anak yatim yang 'yatim' dan keberadaan mereka di panti asuhan. Bagaimanapun anak yatim akan membawa label dirinya yang 'yatim'. Hal ini tanpa disadari kemungkinan menjadi penghambat berkembangnya konsep diri adalah sangat besar.

Tidak hanya itu, keberadaan anak yatim dan.atau biatu di panti asuhan akan mempunyai konsep diri keluarga yang cenderung negatif. Hal ini dikarenakan anak asuh panti: asuhan yatim telah terlabeli dengan label 'anak yatim' yang perlu dikasihani. Artinya label yang muncul secara internal dan juga didukung oleh pandangan lingkungan sosialnya menjadi mereka harus tarik ulur dalam menilai diri mereka sendiri. Kalau mereka menyatakan dalarn dirinya bahwa ia adalah sama dengan anak yang lain, namun kenyataannya ia memang berada di panti asuhan yang biaya hidupnya ditanggung orang lain. Walaupun anak-anak lain (yang masih mempunyai ayah dan ibu) biaya hidup dan se kolah masih ditanggung orang tua mereka, namun hal tersebut masih terasa berbeda antara bergantung kepada orang tua dengan bergantung kepada orang lain.
Pengaruh yang lain adalah pengaruh negatif lingkungan yang berasal dari internal dan eksternal asrama. Pengaruh negatif yang berasal dari internal asrama antara lain adalah pergaulan antar sesama anak asuh. Dalam pergaulan anak yang banyak, seperti di asrama, tidak mustahil ada anak yang kurang bisa menempatkan diri dalam pergaulan; iri, dengki, benci, perselisihan, pertengkaran dan lain-lain. Hal ini pada gilirannya menyebabkan situasi yang tidak kondusif dalam membangun konsep diri yang positif, seperti saling mengejek dengan memberi label yang jelek dan membuka kejelekandi depan orang banyak.

Secara singkat dapat disimpulkan bahwa konsep diri pribadi dan konsep diri sosjal perlu mendapat perhatian yang tinggi dalam usaha meningkatkan konep diri positif anak asuh, yang pada gilirannya dapat mempengaruhi perkembangan kemandirian. Adapun konsep diri yang lain, yaitu konsep dili akademis, konsep diri fisik, konsep diri moral etik dan konsep diri keluarga atau asrama menurut pengamatan peneliti sudah bagus.

Peneliti berpendapat bahwa untuk menghilangkan penghambat perkembangan konsep diri yang beruba label yatim dan anak asrama tersebut di atas perlu dilakukan penyadaran melalui diskusi partisipatif dan mempertebal keyakinan individu yang bersangkutan tentang posisinya dalam pandangan Tuhan Sang Maha Pencipta dan posisinya dalam hubungannya dengan manusia. Keyakinan seperti "Di sini tidak ada penyesalan, yang ada adalah cinta kepada Allah dan rasul-Nya serta mengerti hak dan kewajibannya sebagai hamba."

Kolinearitas antara kompetensi interpersonal dengan konsep diri disebabkan oleh faktor-faktor kompetensi interpersonal dan konsep diri mempunyai keterkaitan yang erat. Hubungan tersebut dapat dilihat dari aspek percaya diri pada aspek konsep diri dan subaspek kompetensi interperSonal. 


\section{SIMPULAN}

Beberapa temuan dalam penelitian ini, yaitu; (1) terdapat hubungan yang signifikan antara kompetensi interpersonal dan konsep diri dengan kemandirian anak asuh panti asuhan yatim, (2) terdapat hubungan yang signifikan antara kompetensi interpersonal dangan kemandirian anak asuh panti asuhan dengan mengontrol konsep diri, (3) terdapat hubungan yang signifikan antara konsep diri dengan kemadnirian anak asuh pant asuhan dengan mengontrol kompetensi interpersonal. Selain itu, penelitian ini menemukan bahwa kemandirian, kompetensi interpersonal dan konsep diri yang dimiliki anak asuh di panti asuhan yatim Islam Kota Yogyakarta adalah sedang.

Dari hasil penelitian ini diperoleh strategi optimalisasi pengembangan kemandirian anak asuh panti asuhan yatim, selain dengan pola asuh yang demokratis dapat juga melalui pengembangan kompetensi interpersonal dan konsep diri dengan jalan: (1) melaui pelatihan-pelatihan seperti pelatihan kerja sama (sepertiout Bound Training), pelatihan manjemen diri, pelatihan manajemen konflik, pelathan pengembangan asertivitas, pelatihan $\mathrm{MC}$, pelatihan pidato dan lain-lain; (2) melalui pengkondisian lingkungan asrama dengan lebih mengedepankan sikap menghargai diri sendiri dan orang lain; (3) diskusi partisipatif anak asuh mengenai materi keagamaan yang bersifat sosial, dan pengembangan atau mempertinggi serta memperdalam kesadaran tentang hubungan dirinya sebagai makhluk Tuhan Pencipta alam semesta, yaitu Allah SWT.

\section{SARAN}

Berpijak pada hasil penelitian tersebut, peneliti menyarankan kepada: (1) anak panti asuhan agar mengembangkan sikap bergauł antar individu dengan sewajarnya, dengan tanpa mengedepankan sikap berlebih-lebihan, lebih percaya dini, dan lebih mengedepankan pergaulan yang bermakna; (2) pembina, pengasuh dan ustadz agar mengagendakan pelatihan dan atau diskusiyang mendorong berkembangnya kompetensi interpersonal dan konsep diri yang optimal, yang pada gilirannya mempertinggi sikap kemandirian anak asuh panti asuhan yatim. Selain itu, pembina atau pengasuh hendaknya tetap menjaga terkondisinya asrama yang saling menghargai serta mempertinggi kesadaran kepada anak asuh tentang hubungannya dengan Allah SWT dan dengan manusia.

Saran yang lain, peneliti tujukan kepada Dinas Sosial dan akademisi. Untuk dua pinak ini peneliti menyarankan agar mempertinggi intensitas penelitian, seminar dan diskusi ilmiah tentang kemandiran anak asuh panti asuhan yatim. Selanjutnya, hasilnya dituangkan dalarn susunan program teknis dan kemudian merekomendasikan kepada instansi atau pihak terkait.

\section{DAFTAR PUSTAKA}

Andayani, B dan Alfiati, T. 1996. Konsep Diri, Harga Diri, dan Kepercayaan Diri Remaja. Jumal Psikologi. Edisi Khusus Ulang Tahun XXXIl; Hal. 23-30.

Azwar, S. 1993. Kelompok Subyek ini Memiliki Harga Diri yang Rendah; Kok Tahun Buletin Psikologi. No. 2, Tahun 1993, Hal. 13-17.

1997. Reliabilitas dan Validitas.

Yogyakarta. Pustaka Pelajar.

1999. Penyusunan Skara Psikologi.

Yogyakarta. Pustaka Pelajar.

Departemen Agama FI. 1984.Al-Quran dan Terjemahnya. Jakarta. Proyek Pengada an Kitab Suci A-Qur'an Departemen Agama R. 
Djunanah. 1999. "Pengaruh SikapPenerimaan Orangtua dan Kemandirian Siswa SMU UII Yogyakarta. " Laporan Penelitian (tidakditerbitkan). Yogyakarta. Lembaga Penelitian Universitas islam Indonesia.

Goble, F. G. 1994. MazhabKetiga: Psikologi Humanistk Abraham Maslow. Terjemahan Supratinya. Yogyakarta. Penerbit Kanisius.

Hadi. S, 1987. MetodologiResearohJilid2. Yogyakarta. Yayasan Peneritan Fakultas Psikologi Universilas Gadjah Mada.

Hardy; $M$ dan Heyes, S. 1988. Pengantar Pslkologi. Terjemahan Soenardji. Jakarta. Erlangga.

Helmi, A. F. 1995. Konsep dan Teknik Pengenalan Diri. Buletin PsikologiTahun lil No. 2 Desember 1995, Hal 13-19.

Hurlock, E. B. 1995. Perkembangan Anak Jilld 2 Terjemahan Meitasari Tjandrasa. Jakarta. Erlangga.

—. 1994. Psikologi Perkembangan Suatu Pendekatan Sepanjang Rentang Ke hidupan. Jakarta. Erlangga.

Idnus, M. 1999. "Menuju Kreatif dan Mandiri. Laporan Diskusi Panel (tidak ditebitkan). Yogyakarta. Lembaga Penelitian UII.

Iriani, N 1995. Pengaruh PelatihanAsertivitas Terhadap Peningkatan Harga Diri. Buletin Ilmiah Kogrisi. Nomor 2 Th. II 1995, Hal. 1-6.

Kartono, K dan Gulo, D. 1987. Kamus Psikologi. Bandung. CV Pionir.

Lukman, M. \& Abdi, S. 1999. "Dari Panti Asuhan Menuju Prbadiyang Mandiri dan Kreatif." Laporan penelitian Lomba Kaya Tulis Ilmiah Mahasiswa Bidang Pendidikan Wilayah $B$ (tidak diterbitkan).
Bandung. Panitia LKTI Bidang Pendidikan Wilayah B Universitas Pendidikan Indonesia.

Mulyati, R. 1997. Kompetensi Interpersonal PadaAnak Panti Asuhan Dengan Sistem Pengasuhan Tradisional dan Anak Panti Asuhan Dengan Sistem Pengasuhan bu Asuh. Jumal Psikologika. Nomor 4 Th. II 1997. Yogyakarta. Fakultas Psikologi Universitas Islam indonesia.

Nashori, F. 1999. Hubungan Antara Reigiusitas dengan Kemandirian pada SIswa SMU. Laporan Penelitian. Yogyakarta. Lembaga Penelitian Ull.

,- 2000 . Hubungan Antara Kematangan Beragama, Konsep Diri dan Jenis Kelamin dengan Kompetensi Interpersonal. Tesis (tidakditeritkan). Yogyakarta. Program Pasca Sarjana Fakultas Psikologi UGM.

Nuryoto, S. 1993. Kemandirlan Remaja Ditinjau Dart Tahap Perkembangan, Jenis Kelamin dan Peran Jenis. Jurnat Psikologi. Nomor 2 Th. XX 1993. Yogyakarta. Fakultas Psikologi UGM.

Partosuwido, S.R. 1993. Penyesuaian Diri Mahasiswa Dalam Kaitannya Dengan Konsep Dirt, Pusat Kendali dan Status Perguruan Tinggi. Jurnal Psikologi. Nomor 1 Th. XX Juni 1993. Yogyakarta. Fakultas Psikologi UGM.

Poerwadarminta, W.J.S. 1995. Kamus Umum Bahasa Indonesia. Jakarta. Balai Pustaka.

Rahmat, J. 1998. Psikologi Komunikasi. Bandung. Rosda Karya.

Robins, S. P. 1996. Perilaku Organisasi: Konsep, Kontroversi dan Aplikasi. Jakarta. PT Prenhallindo. 
Saan, Z. \&Ancok, D. 1989. Korelasi Antara Konsep Dirl Multidimensional dan Prestasi Akademik. Laporan Penelifian. Berkala Penelitian Pasca Sarjana (BPPS), 2 (3A), Hal. 519-529.

Santoso, S. 2000. SPSS: Mengolah Data Statistik Secara Profesional, Jakarta. Gramedia.

Sears, D. O., Freedman, J.L., dan Peplau. L.A.1994. Psikologi Sosial Jilid I.
Terjemahan Michael Adryanto dan Savitri Soekrisno. Jakarta. Erlangga.

Sugiyono. 1997. Statistika untuk Penelfian. Bandung. Alfabeta.

Thalib, S.B. 1996. Kernatangan Pilihan Karir Ditinjau dari Konsep Diri dan Prestasi Belajar Siswa Kelas III SMU Negeri Kabupaten Bulukumba. Tesis (tidak diterbitkan. Yogyakarta. Program Pasca Sarjana Universitas Gadjah Mada. 